\title{
Seasonal variation of hemato-biochemical parameters in indigenous pig: Zovawk of Mizoram
}

\author{
P. Mayengbam and T. C. Tolenkhomba
}

\author{
Department of Veterinary Physiology and Biochemistry, College of Veterinary Sciences and Animal Husbandry, Central \\ Agricultural University, Selesih, Aizawl, Mizoram, India. \\ Corresponding author: Prava Mayengbam, e-mail: dr_prava@rediffmail.com, TCT: drkhomba10@gmail.com \\ Received: 17-02-2015, Revised: 01-05-2015, Accepted: 07-05-2015, Published online: 17-06-2015
}

doi: 10.14202/vetworld.2015.732-737 How to cite this article: Mayengbam P, Tolenkhomba TC (2015) Seasonal variation of hemato-biochemical parameters in indigenous pig: Zovawk of Mizoram, Veterinary World 8(6): 732-737.

\begin{abstract}
Aim: To investigate the influence of season on erythrocyte picture, plasma enzyme and electrolyte profile of local pig of Mizoram at a different age.

Materials and Methods: A volume of $2 \mathrm{ml}$ of blood samples were collected from 72 Zovawk pigs of three different age groups viz. pre-weaning, grower and adult pigs reared in College of Veterinary Sciences and Animal Husbandry Selesih, Aizawl, Mizoram, India, livestock farm during summer and winter in order to find out influence of season on erythrocyte picture, enzyme and electrolyte profile. The hematological parameters were estimated by using an automatic blood analyzer. The biochemical parameters were estimated by using diagnostic kits.

Results: The grower pigs had lower hemoglobin (Hb), packed cell volume (PCV), mean corpuscular volume (MCV), mean corpuscular $\mathrm{Hb}(\mathrm{MCH})$ during summer, rainy and winter seasons $(\mathrm{p}<0.05)$ and lower $\mathrm{MCH}$ concentration $(\mathrm{MCHC})$ during summer season $(\mathrm{p}<0.05)$. Adult pigs had lower $\mathrm{Hb}$ with higher total erythrocyte count in rainy season. PCV and MCV of adult pigs decreased in summer $(\mathrm{p}<0.05)$. Serum glutamic oxaloacetic transaminase activity of both the grower and adult groups increased during summer and rainy seasons $(\mathrm{p}<0.05)$. Zovawk pigs had higher sodium $(\mathrm{Na})$ and lower potassium $(\mathrm{K})$ in rainy season $(\mathrm{p}<0.05)$. Pre-weaning piglets had higher $\mathrm{Na}, \mathrm{K}$, calcium $(\mathrm{Ca})$, and magnesium $(\mathrm{Mg})$ in summer than in winter. Grower pigs had higher $\mathrm{Na}, \mathrm{K}$ and $\mathrm{Ca}$ in summer $(\mathrm{p}<0.05)$. Pi of pre-weaning and grower groups was higher in winter. Adult pigs had lower alkaline phosphatase activity and $\mathrm{Ca}$ in summer and higher $\mathrm{Pi}$ and $\mathrm{Mg}$ in winter $(\mathrm{p}<0.05)$.
\end{abstract}

Conclusion: Seasonal variation in some hemato-biochemical parameters of Zovawk pig were investigated. Influence of season on the hemato-biochemical profile was most evident during the grower stage, followed by adults and pre-weaning piglets.

Keywords: enzyme, electrolyte, hematology, Mizoram, pig, Zovawk.

\section{Introduction}

Physiological signs of heat stress in pigs include an increase in respiration rate, rectal temperature, pulse rate, reduction in feed intake and behavioral adjustments. Heat stress is one of the major concerns in pig farming during summer as pigs do not have functional sweat glands to remove efficiently body heat, unlike other livestock species. Pigs adopt evaporative heat loss mechanism in order to dissipate heat during heat load. High humidity causes physiological signs of heat stress at lower ambient temperature, and the impact of heat stress is more when high humidity exists in the presence of high ambient temperature $[1,2]$. Under the heat stress, penalties to efficient performance, production, reproduction, feed conversion, health and welfare of animals can be severe as it is well-documented $[3,4]$. A number of hematological and biochemical parameters also showed variations in the presence of stress due to high ambient temperature and relative humidity $[4,5]$.

The Zovawk pigs whose home tract is in different parts of Mizoram state in India occupies

Copyright: The authors. This article is an open access article licensed under the terms of the Creative Commons Attributin License (http:// creative commons.org/licenses/by/2.0) which permits unrestricted use, distribution and reproduction in any medium, provided the work is properly cited. only 47,143 out of total pig population of 167,361 in Mizoram [6]. Scientific report on proximate component analysis of body measurements suggested that a few body measurement of Zovawk pigs could be exploited in breeding and selection programs in order to increase its population and also its productivity [7]. Recently, Zovawk pigs had been reported to have normally higher content of hemoglobin $(\mathrm{Hb})$ and total erythrocyte count (TEC) [8] like other indigenous pigs $[9,10]$ and some wild and captive pigs $[11,12]$ which were higher than those reported in other exotic and crossbred pigs [10,13-15]. The content of plasma $\mathrm{Na}$ in Zovawk was found to be higher [16] as compared to that of other indigenous, exotic and crossbred pigs $[13,15,17]$. There is however no literature available to explain the seasonal changes in hematology or blood biochemical profile of pigs domesticated in Mizoram and more particularly the Zovawk pigs of Mizoram.

Mizoram is situated between 92015"-93029" E longitude and 21058"-24035" $\mathrm{N}$ latitude with average elevation $1132 \mathrm{~m}$ above the mean sea level. The state enjoys a pleasant climate throughout the year except in the summer and rainy seasons during which a very high relative humidity prevails [18]. The present study was therefore undertaken in order to investigate 
seasonal variation on erythrocyte picture, plasma enzyme profile and electrolyte status of indigenous pig - Zovawk. The presented data could be utilized as basic information about this kind of pig and application of knowledge in amelioration of stress to Zovawk pigs under conventional rearing system and more particularly to management practices in a state like Mizoram where relative humidity is very high during the summer, which will ultimately facilitate in averting the economic losses.

\section{Materials and Methods}

\section{Ethical approval}

The present investigation was carried out after the approval of the Institutional Animal Ethics Committee.

\section{Animals and blood sampling}

The study was carried out in Zovawk pig of Mizoram reared in the Livestock Farm, College of Veterinary Sciences and Animal Husbandry, Central Agricultural University, Selesih, Aizawl, Mizoram, India. The study comprised of three different groups, pre-weaning group (1 month old), grower group (2.5 months old) and adults (12-14 months old) and each groups comprised of 12 animals of either sexes. The piglets were kept with the mother till the weaning of the piglets on $56^{\text {th }}$ day thereafter they were being given grower diets. The adult female pigs were in the first parity and the adult males had given $1^{\text {st }}$ service.

The body weight of animals was recorded 1 day before the blood sampling. The average body weight of pigs used in the present investigation in pre-weaning, grower and adults groups were $2.39 \pm 0.14 \mathrm{~kg}$, $4.98 \pm 0.24 \mathrm{~kg}$ and $59.22 \pm 1.73 \mathrm{~kg}$, respectively. Blood sampling was done by puncturing anterior venacava in heparinized vacutainers. Blood samples were collected in three different periods i.e., summer, rainy and winter seasons. Cold chain was maintained during the transit of the samples from farm to the laboratory.

\section{Collection of meteorological data}

Three different seasons of the calendar year were selected viz. summer season (March-June), rainy season (July-October) and winter season (November-February). Meteorological data were recorded from the automatic weather Station (WatchDog, Spectrum Technologies, Inc.) located inside the campus of College of Veterinary Sciences and Animal Husbandry, Central Agricultural University, Selesih, Aizawl, Mizoram, India. The average minimum ambient temperature $\left(\mathrm{T}_{\text {min. }}\right)$, average maximum ambient temperature $\left(\mathrm{T}_{\text {max }}\right)$, average minimum relative humidity $\left(\mathrm{R} . \mathrm{H}_{\min }\right)$, average maximum relative humidity $\left(\right.$ R. $H_{\text {max }}$ ) and temperature humidity index (THI) were calculated and presented in Table-1. THI was calculated by using the following formula:

$\mathrm{THI}=0.8 \mathrm{~T}+\frac{\mathrm{RHT}-14.4}{100}+46.4$
Table-1: Ambient temperature, relative humidity and THI in summer, rainy and winter season at Selesih, Aizawl.

\begin{tabular}{|c|c|c|c|c|c|}
\hline \multirow[t]{2}{*}{ Season } & \multicolumn{2}{|c|}{$\begin{array}{c}\text { Average } \\
\text { ambient } \\
\text { temperature } \\
\left({ }^{\circ} \mathrm{C}\right)\end{array}$} & \multicolumn{2}{|c|}{$\begin{array}{c}\text { Average } \\
\text { relative } \\
\text { humidity } \\
(\%)\end{array}$} & \multirow[t]{2}{*}{$\begin{array}{c}\text { Average } \\
\text { THI }\end{array}$} \\
\hline & $\mathbf{T}_{\min }$ & $\mathbf{T}_{\max }$ & $\mathbf{R} \cdot \mathbf{H}_{\text {min }}$ & R. $\mathbf{H}_{\max }$ & \\
\hline Summer & 19.66 & 28.67 & 50.75 & 93.75 & 72.79 \\
\hline Rainy & 20.63 & 28.87 & 71.50 & 97.75 & 74.96 \\
\hline Winter & 14.82 & 25.51 & 49.50 & 84.50 & 66.40 \\
\hline
\end{tabular}

THI=Temperature humidity index

Where, T and RH are average ambient temperature and average relative humidity respectively [19].

\section{Analysis of samples}

Hematological parameters were analyzed by using VetscanHM5 immediately after collection. Plasma was separated from whole blood by centrifugation at $3000 \mathrm{rpm}$ for $20 \mathrm{~min}$ immediately after collection of blood. All the parameters viz. serum glutamic-oxaloacetic transaminase (SGOT), serum glutamic pyruvic transaminase (SGPT), alkaline phosphatase (ALP), sodium $(\mathrm{Na})$, potassium $(\mathrm{K})$, chloride $(\mathrm{Cl})$, calcium $(\mathrm{Ca})$, phosphorus $(\mathrm{Pi})$ and magnesium $(\mathrm{Mg})$ were analyzed in the plasma. All the parameters were estimated by using diagnostic kits from M/s Crest Biosystems, India by following standard protocols (viz. SGOT and SGPT by Reitman and Frankel's method, ALP by modified Kind and King's method, $\mathrm{Na}$ and $\mathrm{K}$ by colorimetric method, $\mathrm{Cl}$ by Thiocyanate method, $\mathrm{Ca}$ by o-cresolphthalein complexone method, Pi by Molybdate U.V. method, and $\mathrm{Mg}$ by Calmagite method) by using a UV-Vis Spectrophotometer (Chemito-Spectroscan 2600).

\section{Statistical analysis}

Data were analyzed using the SYSTAT 12 by applying independent t-test to compare between the seasons and one-way ANOVA, followed by Fisher's least significant difference test for post-hoc multiple comparisons to evaluate the effect of different age groups on hematological parameters.

\section{Results}

The seasonal variation in mean \pm standard error of erythrocyte picture, enzyme profile and electrolyte profile of Zovawk pig in three different groups viz. pre-weaning, grower and adult groups are presented in Tables 2-4 respectively.

\section{Erythrocyte profile}

Erythrocyte profile of pre-weaning Zovawk piglets was not influenced by season. The grower pigs were found to have significantly lower $\mathrm{Hb}$, packed cell volume (PCV), mean corpuscular volume (MCV), mean corpuscular $\mathrm{Hb}(\mathrm{MCH})$ in summer and rainy season than in winter $(\mathrm{p}<0.05)$. The $\mathrm{MCH}$ concentration (MCHC) of grower pigs was lower in summer than in winter $(\mathrm{p}<0.05)$. The adult Zovawk pigs had higher TEC and lowered $\mathrm{Hb}$ during the rainy season as compared to that in summer and winter $(\mathrm{p}<0.05)$. Adult 
Available at www.veterinaryworld.org/Vol.8/June-2015/8.pdf

Table-2: Effect of season on hematological profile of Zovawk in different age groups.

\begin{tabular}{|c|c|c|c|c|}
\hline Parameter & Season & Pre-weaning & Grower & Adult \\
\hline \multirow[t]{3}{*}{ TEC $\left(\times 10^{6} / \mu \mathrm{l}\right)$} & Summer & $8.09 \pm 0.48^{b}$ & $9.84 \pm 0.27^{a}$ & $8.78 \pm 0.35^{\mathrm{ab}}{ }_{\mathrm{B}}$ \\
\hline & Rainy & $8.14 \pm 0.15^{c}$ & $10.24 \pm 0.65^{b}$ & $16.11 \pm 1.0^{a}{ }_{A}$ \\
\hline & Winter & $8.10 \pm 0.17^{b}$ & $10.66 \pm 0.54^{a}$ & $8.84 \pm 0.46^{\mathrm{b}}{ }_{B}^{\mathrm{A}}$ \\
\hline \multirow[t]{3}{*}{$\mathrm{Hb}(\mathrm{g} / \mathrm{dl})$} & Summer & $13.03 \pm 3.02^{b}$ & $12.91 \pm 0.33^{b}{ }_{B}$ & $16.76 \pm 0.32^{\mathrm{a}}{ }_{\mathrm{A}}$ \\
\hline & Rainy & $13.67 \pm 0.23^{a}$ & $12.78 \pm 0.72^{a b}$ & $11.33 \pm 1.15^{\mathrm{b}}{ }^{\mathrm{A}}$ \\
\hline & Winter & $13.53 \pm 0.22^{b}$ & $17.75 \pm 0.83^{a}$ & $17.36 \pm 1.09^{a}$ \\
\hline \multirow[t]{3}{*}{ PCV (\%) } & Summer & $44.54 \pm 2.92^{b}$ & $43.28 \pm 0.99^{b_{B}^{A}}$ & $53.15 \pm 1.93^{a_{B}}{ }_{B}$ \\
\hline & Rainy & $45.15 \pm 0.73^{b}$ & $41.86 \pm 2.28^{b}{ }_{B}^{b}$ & $60.10 \pm 2.87^{\mathrm{a}}{ }_{\mathrm{AB}}$ \\
\hline & Winter & $45.31 \pm 0.62^{b}$ & $55.85 \pm 2.64^{\mathrm{a}}{ }_{\mathrm{A}}$ & $60.42 \pm 2.65^{\mathrm{a}}{ }_{\mathrm{A}}$ \\
\hline \multirow[t]{3}{*}{$\operatorname{MCV}(\mathrm{fl})$} & Summer & $56.11 \pm 3.44^{a}$ & $44.19 \pm 1.13^{\mathrm{b}^{\mathrm{A}}}$ & $61.07 \pm 1.97^{a^{A}}$ \\
\hline & Rainy & $55.58 \pm 0.45^{a}$ & $41.83 \pm 2.35^{\mathrm{b}}{ }_{B}$ & $60.44 \pm 0.99^{a}{ }_{B}$ \\
\hline & Winter & $56.08 \pm 0.63^{b}$ & $52.58 \pm 0.62^{\mathrm{b}}{ }_{\mathrm{A}}^{\mathrm{b}}$ & $69.17 \pm 3.39^{a}{ }_{A}$ \\
\hline \multirow[t]{3}{*}{$\mathrm{MCH}(\mathrm{pg})$} & summer & $16.37 \pm 0.97^{b}$ & $13.17 \pm 0.32^{\mathrm{c}}{ }^{\mathrm{A}}$ & $19.48 \pm 1.04^{a}{ }_{A B}$ \\
\hline & Rainy & $16.82 \pm 0.21^{\mathrm{a}}$ & $12.67 \pm 0.57^{b}{ }_{B}^{b}$ & $17.62 \pm 0.35^{\mathrm{a}}{ }_{\mathrm{B}}$ \\
\hline & Winter & $16.73 \pm 0.17^{b}$ & $16.69 \pm 0.26^{\mathrm{b}}$ & $20.21 \pm 1.09^{\mathrm{a}}{ }_{\mathrm{A}}$ \\
\hline \multirow[t]{3}{*}{$\mathrm{MCHC}(\%)$} & Summer & $29.29 \pm 0.54$ & $29.82 \pm 0.20_{B}^{A}$ & $31.93 \pm 1.22^{\mathrm{A}}$ \\
\hline & Rainy & $30.29 \pm 0.32$ & $30.52 \pm 0.55_{A B}^{\circ}$ & $29.21 \pm 0.55$ \\
\hline & Winter & $29.84 \pm 0.28$ & $31.79 \pm 0.38_{A}$ & $29.01 \pm 1.62$ \\
\hline
\end{tabular}

a-c Values in the same row with different superscripts differ significantly $(p<0.05)$, ${ }_{A-B}$ Values in the same column with different subscripts differ significantly $(p<0.05)$, TEC $=$ Total erythrocyte count, $\mathrm{Hb}=$ Hemoglobin, $P C V=$ Packed cell volume, $\mathrm{MCV}=$ Mean corpuscular volume, $\mathrm{MCH}=$ Mean corpuscular hemoglobin, $\mathrm{MCHC}=$ Mean corpuscular hemoglobin concentration

Table-3: Effect of season on SGOT, SGPT and ALP profile of Zovawk in different age groups.

\begin{tabular}{|c|c|c|c|c|}
\hline Parameter & Season & Pre-weaning & Grower & Adult \\
\hline \multirow[t]{3}{*}{ SGOT (U/L) } & Summer & $37.25 \pm 4.63^{b}$ & $47.63 \pm 1.47^{a}$ & $54.50 \pm 2.24_{A}^{a}$ \\
\hline & Rainy & $36.29 \pm 4.16^{b}$ & $52.92 \pm 2.66_{\mathrm{A}}^{\mathrm{A}}$ & $59.33 \pm 3.00^{\mathrm{a}}{ }_{\mathrm{A}}$ \\
\hline & Winter & $38.88 \pm 4.76$ & $35.90 \pm 3.02_{B}^{A}$ & $37.58 \pm 3.81^{\mathrm{B}}$ \\
\hline \multirow[t]{3}{*}{ SGPT (U/L) } & Summer & $23.33 \pm 2.01^{b}$ & $28.13 \pm 1.46_{\mathrm{A}}^{\mathrm{b}}$ & $42.08 \pm 2.86^{a}$ \\
\hline & Rainy & $22.83 \pm 2.33^{a}$ & $23.92 \pm 0.76^{a^{A}}$ & $40.50 \pm 3.10^{b}$ \\
\hline & Winter & $22.21 \pm 2.58^{b}$ & $25.62 \pm 1.58^{\mathrm{b}}{ }^{\mathrm{B}}$ & $47.83 \pm 2.49^{a}$ \\
\hline \multirow[t]{3}{*}{ ALP (Ka) } & Summer & $36.03 \pm 3.49^{a}$ & $15.09 \pm 1.45^{\mathrm{b}}{ }_{\mathrm{AB}}^{\mathrm{AB}}$ & $4.93 \pm 0.20^{c}$ \\
\hline & Rainy & $29.69 \pm 3.19^{a}$ & $20.11 \pm 2.83^{\mathrm{b}}$ & $8.74 \pm 0.87^{c}$ \\
\hline & Winter & $36.85 \pm 2.94^{a}$ & $14.29 \pm 0.98^{{ }^{\mathrm{b}}}{ }_{\mathrm{B}}$ & $8.79 \pm 1.11^{c^{A}}$ \\
\hline
\end{tabular}

${ }^{a-c}$ Values in the same row with different superscripts differ significantly $(p<0.05)$, ${ }_{\text {V }}$ Values in the same column with different subscripts differ significantly $(p<0.05)$, SGOT=Serum glutamic oxaloacetic transaminase, SGPT=Serum glutamic pyruvic transaminase, ALP=Alkaline phosphatase

Table-4: Effect of season on electrolyte profile of Zovawk in different age groups.

\begin{tabular}{|c|c|c|c|c|}
\hline Parameter & Season & Pre-weaning & Grower & Adult \\
\hline \multirow[t]{3}{*}{ Sodium (mmol/L) } & Summer & $166.04 \pm 5.03_{B}$ & $169.77 \pm 3.81_{B}$ & $172.59 \pm 5.38_{B}$ \\
\hline & Rainy & $192.69 \pm 5.02_{A}^{B}$ & $190.09 \pm 3.58_{A}^{B}$ & $197.51 \pm 5.58_{\mathrm{A}}$ \\
\hline & Winter & $152.74 \pm 3.63_{C}$ & $152.29 \pm 2.55_{C}^{A}$ & $162.14 \pm 5.32_{B}$ \\
\hline \multirow[t]{3}{*}{ Potassium (mmol/L) } & Summer & $5.78 \pm 0.36_{A}^{b}$ & $4.09 \pm 0.04_{A}^{c}$ & $6.44 \pm 0.15^{a}{ }_{A}$ \\
\hline & Rainy & $3.44 \pm 0.21_{B}^{\mathrm{b}}$ & $3.51 \pm 0.14^{\mathrm{b}}{ }_{B}$ & $4.07 \pm 0.16^{a}{ }_{B}$ \\
\hline & Winter & $5.41 \pm 0.20^{\mathrm{a}}{ }_{\mathrm{A}}$ & $3.54 \pm 0.17^{b}{ }_{B}$ & $6.16 \pm 0.37^{\mathrm{a}}{ }_{\mathrm{A}}$ \\
\hline \multirow[t]{3}{*}{ Chloride (mmol/L) } & Summer & $99.68 \pm 1.21^{\mathrm{a}}$ & $92.70 \pm 0.35^{\mathrm{b}}{ }_{B}$ & $94.06 \pm 0.94^{\mathrm{a}}$ \\
\hline & Rainy & $106.53 \pm 7.20$ & $94.28 \pm 0.87_{\mathrm{B}}^{\circ}$ & $97.19 \pm 0.83$ \\
\hline & Winter & $113.60 \pm 3.89^{b}$ & $131.39 \pm 6.82^{\mathrm{a}}{ }_{\mathrm{A}}$ & $100.18 \pm 5.07^{b}$ \\
\hline \multirow[t]{3}{*}{ Calcium (mg/dl) } & Summer & $9.86 \pm 0.38_{\mathrm{A}}^{\mathrm{a}}$ & $8.77 \pm 0.31_{A}^{b}$ & $9.05 \pm 0.19^{\mathrm{ab}} \mathrm{c}$ \\
\hline & Rainy & $8.39 \pm 0.54^{b}{ }_{B}$ & $7.46 \pm 0.36^{b}{ }_{B}$ & $11.36 \pm 0.51_{B}^{a}$ \\
\hline & Winter & $7.27 \pm 0.25^{\mathrm{b}}{ }_{B}$ & $6.97 \pm 0.28^{\mathrm{b}}{ }_{B}$ & $14.31 \pm 0.36^{a}{ }_{A}$ \\
\hline \multirow[t]{3}{*}{ Phosphorus (mg/dl) } & Summer & $4.85 \pm 0.19_{B}^{B}$ & $4.58 \pm 0.13_{B}$ & $4.85 \pm 0.35_{A}^{A}$ \\
\hline & Rainy & $3.89 \pm 0.19^{\mathrm{b}}{ }_{\mathrm{C}}$ & $5.02 \pm 0.15^{a}{ }_{B}$ & $4.08 \pm 0.17^{b}$ \\
\hline & winter & $9.83 \pm 0.41^{a}{ }_{A}$ & $7.20 \pm 0.53_{\mathrm{A}}^{\mathrm{b}}$ & $3.23 \pm 0.16^{\mathrm{c}}{ }_{\mathrm{B}}$ \\
\hline \multirow[t]{3}{*}{ Magnesium (mEq/L) } & summer & $2.98 \pm 0.21_{\mathrm{A}}$ & $3.18 \pm 0.10$ & $2.45 \pm 0.12^{A}$ \\
\hline & rainy & $1.89 \pm 0.02^{b}{ }_{B}$ & $3.05 \pm 0.29^{a}$ & $2.55 \pm 0.15^{\mathrm{a}}$ \\
\hline & winter & $1.87 \pm 0.03_{B}$ & $2.98 \pm 0.23$ & $1.97 \pm 0.02^{\mathrm{B}}$ \\
\hline
\end{tabular}

a-c Values in the same row with different superscripts differ significantly $(p<0.05)$, A-c Values in the same column with different subscripts differ significantly $(p<0.05)$

pigs had lower PCV and MCV in summer than in winter $(\mathrm{p}<0.05)$. During the rainy season, the adult pigs had PCV like in summer and winter however MCV was significantly lower than that in winter $(\mathrm{p}<0.05)$. $\mathrm{MCH}$ of adult pigs was significantly lower in the rainy season than in winter $(\mathrm{p}<0.05)$. 


\section{Enzyme profile}

During the pre-weaning period, SGOT, SGPT and ALP activities were not influenced by season. The SGOT activity of grower and adult pigs was higher in summer and rainy seasons than in winter $(p<0.05)$. SGPT was influenced by season only during grower stage $(p<0.05)$ with higher activity in summer as compared to that in the rainy season. In growers, ALP activity was found to be lower in winter than in rainy season $(p<0.05)$. ALP activity of adult pigs was lower in summer than in rainy and winter seasons $(p<0.05)$.

\section{Electrolyte profile}

Zovawk pigs had higher $\mathrm{Na}$ and lower $\mathrm{K}$ during the rainy season $(p<0.05)$. The pre-weaning and grower group had higher $\mathrm{Na}$ in summer than in winter. The grower pigs had higher $\mathrm{K}$ in summer than in winter $(\mathrm{p}<0.05)$. The $\mathrm{Cl}$ level was influenced by season only in grower group with higher values in winter as compared to summer and rainy seasons $(p<0.05)$. The pre-weaning piglets and growers had higher plasma $\mathrm{Ca}$ during the summer than during the winter $(\mathrm{p}<0.05)$ while a reverse trend was recorded for Pi. The adult Zovawk pigs had higher plasma Ca during rainy and winter seasons $(p<0.05)$ while a reverse trend was observed for Pi. The seasonal influence on plasma $\mathrm{Mg}$ of Zovawk was observed during the pre-weaning and adult periods with higher values in summer $(\mathrm{p}<0.05)$ than in winter.

\section{Discussion}

From the present finding it was evident that hematological parameters were least affected by seasonal variation during the pre-weaning period while that of growers was most affected. The record of lower $\mathrm{Hb}$, $\mathrm{PCV}, \mathrm{MCV}, \mathrm{MCH}$ and $\mathrm{MCHC}$ in the blood in growers during the summer and rainy seasons indicated that all the erythrocyte pictures except TEC showed variation due to stress due to higher THI (Table-1). As the grower pigs had been shifted from the mothers' milk and subjected to grower diet, in high demand of nutritious diet in order to complement the overall growth and development of the body, higher THI during summer and rainy season were more stressful than winter as reported in other indigenous and crossbred pigs [5]. Higher THI when the heat load is more, one of the main behavior change recorded in pigs is a reduction in voluntary feed intake to minimize the metabolic heat production [20,21]. Although there was higher demand of nutrients for growth, the animals were probably consuming less feed due to more heat load [20], which resulted to drop in Hb, PCV, MCV, $\mathrm{MCH}$ and $\mathrm{MCHC}$ during summer and rainy seasons in grower group.

In case of adult animals, the pigs had lower $\mathrm{Hb}$ during the rainy season as compared to summer and winter, which might be due to high THI. As these animals are well-adapted animals, there was a compensatory increase in TEC during the rainy season in adult leading to PCV comparable to that of summer and winter. However, PCV and MCV of adult pigs were lower in summer as compared to winter due to thermal stress.

In the present investigation, the SGOT activity of grower and adult pigs was found to be higher in summer and rainy seasons than in winter $(p<0.05)$. The SGOT activity increased from pre-weaning to grower during summer and rainy seasons $(p<0.05)$, but not during winter. From the present finding, it could be assumed that both summer and rainy seasons caused higher SGOT in grower pigs as compared to pre-weaning pigs like in other indigenous pig and crossbred pigs [5]. SGOT activity of adult pigs was higher than that of pre-weaning pigs during the summer but not during the winter, which also indicated that in presence of higher THI, SGOT activity of Zovawk pigs also increased like in other pigs [5].

The presence of higher SGPT during summer in case of grower group might be due to stress as SGPT activity of grower pigs had been shown to increase in stress [22]. The finding of no seasonal influence on SGPT activity in case of adult pigs resembled the previous reports in Gunghroo, Niang Megha and Crossbreds [5]. The adult Zovawk pigs had higher SGPT activity than the pre-weaning and grower pigs as SGPT activity increases with increase in body mass $[23,24]$.

ALP activity declined gradually with age in all the seasons as reflection of the decline in the demand of the enzyme for skeletal growth with age [25]. ALP activity of adult pigs was lower in summer than in rainy and winter seasons, which might be due to summer stress as ALP had been reported to decrease its activity when exposed to heat stress [5]. It had also been reported that in order to maintain stable blood calcium level with lowering serum levels of 25-hydroxyvitamin D during winter, ALP activity in elderly people increased during winter [26]. It could be possible that there was fall of ALP of adult Zovawk pigs due to heat stress during summer and increase in activity of ALP during winter in order to compensate the requirement of vitamin D.

The SGOT and SGPT activities of Zovawk pigs were in the ranges reported in Burmese pigs [27], Ghungroo and Niang Megha and crossbred pigs [5] but were lower than the activities reported in other exotic pigs [15]. ALP activity of Zovawk pigs resembled that of wild boar [11] but were lower than other crossbred pigs $[28,29]$.

Minerals serve many important functions in pig nutrition. These range from structural functions in the bone to a wide variety of chemical reactions essential for maintenance, growth reproduction, and lactation. The presence of higher Na and lower $\mathrm{K}$ during the rainy season in all the age groups indicated an osmotic imbalance in these pigs during rainy season due to high humidity in addition to high ambient temperature. Activation of hypothalamo-pituitary adrenal axis by prevailing stress due to high temperature and 
humidity might have led to secretion of more aldosterone leading to retention of $\mathrm{Na}$ and excretion of $\mathrm{K}$ during the rainy season. Summer stress caused a higher concentration of $\mathrm{Na}$ in the pre-weaning and grower pigs and higher plasma $\mathrm{K}$ in growers. The concentration of plasma $\mathrm{Na}$ and $\mathrm{K}$ during summer and rainy season in growing period was indicative of dehydration with hypernatremia and hyperkalemia, which also caused lower PCV and MCV due to a decrease in intracellular fluid volume [30].

In this study, an increase in plasma $\mathrm{Na}$ and $\mathrm{K}$ during summer were accompanied by a decline in plasma $\mathrm{Cl}$. The Zovawk pigs were found to have lower $\mathrm{Cl}$ in plasma during summer and rainy seasons than during winter with a significant difference recorded in grower pigs. Seasonal variation in plasma $\mathrm{Cl}$ could be due to seasonal variation in $\mathrm{Cl}$ excretion and parathyroid gland activity [31,32]. There is a close relationship between parathyroid hormone synthesis with 1,25-dihydroxyvitamin $\mathrm{D}$ in $\mathrm{Ca}$ homeostasis. Apart from the role of the parathyroid gland in homeothermy of $\mathrm{Ca}$, parathyroid gland overstimulation also resulted to clinical hyperchloremia [33]. Rise in $\mathrm{Cl}$ level of grower pigs during winter season could be due to activation of parathyroid gland for PTH synthesis and secretion in order to compensate low synthesis of vitamin D during winter and restore low plasma $\mathrm{Ca}$ of the pigs during winter to normal.

The grower Zovawk pigs were at the fast growing stage, which required fine control in the balance between the thyroid and parathyroid glands in regulating endogenous calciferol and parathyroid hormone in exhibiting seasonal variation in plasma $\mathrm{Ca}$ and $\mathrm{Cl}$. It had been shown that the pigs required vitamin $\mathrm{D}$ even when receiving diets with higher in calcium and phosphorus than were ordinarily recommended [34]. Exposure of pigs to sufficient solar radiation during December and January had been found to cure rickets [34]. Less exposure of the pre-weaning piglets and growers to solar radiation during the winter might have led to low vitamin D synthesis which might have resulted in drop in the plasma $\mathrm{Ca}$ in those pigs during winter and the combined effect of both might have led to activation of parathyroid gland during winter.

The Mg homeostasis is a result of balance between intestinal absorption and renal excretion with additional regulation by the adrenals, thyroids and parathyroid glands [25]. Mg ion had an effect on parathyroid secretory rate similar to that of $\mathrm{Ca}$, but its effect was not equipotent to that of $\mathrm{Ca}$ [25]. The finding of higher plasma $\mathrm{Mg}$ during summer in the presence of higher $\mathrm{Ca}$ in the present study agreed the effects of $\mathrm{Ca}$ in control of PTH secretion, together with its preponderance over $\mathrm{Mg}$ in extracellular fluid suggesting a secondary role for $\mathrm{Mg}$ in parathyroid control [25].

\section{Conclusion}

The erythrocyte profile, plasma enzyme activity and electrolyte status of Zovawk pigs were influenced by season. This study revealed a close association between the hemato-biochemical parameters in different seasons. The hemato-biochemical profile of grower pigs was most affected by seasonal variation, followed by adults and pre-weaning piglets. The changes in hemato-biochemical profile indicated that both summer and rainy seasons were stressful to Zovawk pigs. The estimated hematological and biochemical parameters could be used as measure of stress in Zavawk pigs.

\section{Authors' Contributions}

PM performed the analysis of blood samples and prepared the manuscript. TCT helped during the blood sample collection and the statistical analysis of the data. Both authors drafted and revised the manuscript. Both authors read and approved the final manuscript.

\section{Acknowledgments}

The authors are grateful to the Dean, College of Veterinary Sciences and Animal Husbandry and Vice Chancellor Central Agricultural University, Selesih, Aizawl, Mizoram for providing funds for Intramural Research Project to carry out the experiments and Project Investigator, AICRP on Pigs, College of Veterinary Science and Animal Husbandry, Selesih, Aizawl, Mizoram for providing pigs for blood sampling.

\section{Competing Interests}

The authors declare that they have no competing interests.

\section{References}

1. Huynh, T.T.T., Aarnink, A.J.A., Verstegen, M.W.A., Gerrits, W.J.J., Heetkamp, M.J.W., Kemp, B. and Canh, T.T. (2005) Effects of increasing temperatures on physiological changes in pigs at different relative humidities. J. Anim. Sci., 83(6): 1385-1396.

2. Nienaber, J.A., Hahn, G.L., McDonald, T.P. and Korthals, R.L. (1996) Feeding patterns and swine performance in hot environments. Trans. Am. Soc. Agric. Eng., 39: 195-202.

3. Hahn, G.L., Nienaber, J.A. and DeShazer, J.A. (1987) Air temperature influences on swine performance and behaviour. Appl. Eng. Agric., 3(2): 295-302.

4. Pearce, S.C., Mani, V., Weber, T.E., Rhoads, R.P., Patience, J.F., Baumgard, L.H. and Gabler, N.K. (2013) Heat stress and reduced plane of nutrition decreases intestinal integrity and function in pigs. J. Anim. Sci., 91(11): 5183-5193.

5. Pourouchottamane, R., Pankaj, P.K., Banik, S., Naskar, S. Venkatsubramanian, V. and Ramana, D.B.V. (2013) Effect of micro-environmental variations on biomolecular profile and performance of pig. J. Agrometeorol., 15(1): 1-6.

6. 18th Livestock Census. (2007) Department of Animal Husbandry, Dairying and Fisheries, Ministry of Agriculture, New Delhi.

7. Tolenkhomba, T.C., Saikia, P., Hmar, L., Lalthazuali, Prava, M. and Singh, N.S. (2013) Principal component analysis of body measurements in Mizo local pigs. Indian $J$. Vet. Res., 22(1): 26-31.

8. Mayengbam, P., Tolenkhomba, T.C. and Ali, M.A. (2014) Hematological profile of Zovawk-and indigenous pig of Mizoram. Vet. World, 7: 505-508.

9. Friendship, R.M., Lumsden, J.H., McMillan, I. and Wilson, M.R. (1984) Hematology and biochemistry reference values for Ontario swine. Can. J. Comp. Med., 48(4): 390-393. 
10. De, A.K., Kundu, A., Kundu, M.S., Sunder, J. and Jeyakumar, S. (2013) Comparative study on haematological traits of endangered Andaman wild pig and other indigenous pig breeds available at Andaman and Nicobar Islands, India. Vet. World, 6(10): 794-798.

11. Harapin, I., Bedrica, L., Hahn, V., Sostaric, B. and Gracner, D. (2003) Haematological and biochemical values in blood of wild boar. Vet. Arch., 73(6): 333-343, 12.

12. Semiadi, G. and Nugraha, R.T.P. (2009) Some notes on biological aspects of captive Javan warty pig (Sus verrucosus). Biodeversitas, 10(3): 124-128.

13. Klem, T.B., Bleken, E., Morberg, H., Thoren, S.I. and Framstad, T. (2010) Hematologic and biochemical reference intervals for Norwegian crossbreed grower pigs. Vet. Clin. Pathol., 39(2): 221-226.

14. Eze, J.I., Onunkwo, J.I., Shyinka, S.V.O., Chah, F.K., Ngene, A.A., Okolinta, N., Nwanta, J.A. and Onyenwe, I.W. (2010) Haematological profiles of pigs raised under intensive management system in south-eastern Nigeria. Nig. Vet. J., 31(2): 115-123.

15. Cooper, C.A., Moraes, L.E., Murray, J.D. and Owens, S.D. (2014) Hematologic and biochemical reference intervals for specific pathogen free 6-week-old Hampshire-Yorkshire crossbred pigs. J. Anim. Sci. Bioctech., 5: 1-5.

16. Mayengbam, P., Tolenkhomba, T.C. Ali, M.A., Saikia, P., Singh, N.S. and Hmar, L. (2012) Electrolyte (Na, K, Cl, Pi and $\mathrm{Mg}$ ) profile of Zovawk pigs of Mizoram, India in different age groups. Int. Mult. Res. J., 2(2): 49-51.

17. Kumaresan, A., Bujarbaruah, K.M., Pathak, K.A., Das, A. and Ramesh, T. (2009) Mineral profiling of local pig-feeds and pigs reared under resource driven production system to reduce porcine mineral deficiency in subtropical hill ecosystem of Northeastern India. Trop. Anim. Health Prod., 41: 669-675.

18. Statistical Abstract. (2003) Department of Agricultural and Minor Irrigation, Government of Mizoram, Aizawl.

19. Johnson, H.D., Ragsdale, A.C., Berry, I.L. and Shanklin, M.D. (1962) Effect of various temperature-humidity combinations on milk production of Holstein cattle. Res. Bull. Missouri Agric. Exp. Station, Bulletin no. 791.

20. Collin, A., Milgan, J.V., Dubbbois, S. and Noblet, J. (2001) Effect of high temperature on feeding behavior and heat production in group-housed young pigs. Br. J. Nutr., 86(1): 63-70.

21. Huynh, T.T.T., Aarnink, A.J.A., Gerrits, W.J.J., Heetkamp, M.J.H., Canh, T.T., Spoolder, H.A.M., Kemp, B. and Verstegen, M.W.A. (2005) Thermal behaviour of growing pigs in response to high temperature and humidity. Appl. Anim. Behav. Sci., 91(1-2): 1-16.
22. Ajuogu, P.K., Latona, P., Ajayi, F.O. and Ekine, O.A. (2010) Influence of wallow on some hematological parameters and serum enzymes in growing pigs. Anim. Prod. Res. Adv., 6(2): 139-142.

23. Salvaggio, A., Pariti, M., Miano, L., Tavanelli, M. and Marzorati, D. (1991) Body mass index and liver enzyme activity in serum. Clin. Chem., 37: 720-723.

24. Kumar, S, Amarappurkar, A. and Amarappurkar, D. (2013) Serum aminotransferase levels in healthy population from western India. Indian J. Med. Res., 138: 894-899.

25. Rosol, T.J. and Capen. C.C. (1999) Calcium-regulating hormones and diseases of abnormal mineral (calcium, phosphorus and magnesium) metabolism. In: Kaneko, J.J., Harvey J.W. and Bruss, M.L. editors. Clinical Biochemistry of Domestic Animals. Harcourt Brace \& Company Asia PTE LTD, Singapore. p619-702.

26. Devgun, M.S., Paterson, C.R. and Martin, B.T. (1981) Seasonal changes in the activity of serum alkaline phosphatase. Enzyme, 26(6): 301-305.

27. Sarma, K., Konwar, B., Ali, A., Das, G., Kalita, G., Ahmed, F.A., Saikia, B., Bayan, H. and Nayan, V. (2011) Haemato-buiochemical parameters of Burmese pig of subtropical hill agro ecosystem. Indian J. Anim. Sci., 81(8): 819-821.

28. Chmielowiec-Koreniowska, A., Tymczyna, L. and Babicz, M. (2012) Assessment of selected parametrs of biochemistry, hematology, immunology and production of pigs fattened in different seasons. Arch. Tierz., 55(5): 469-479.

29. Adenkola, A.Y., Ayo, J.O., Sackey, A.K.B. and Adelaiye, A.B. (2009) Haematological and serum biochemical changes in pigs administered with ascorbic acid and transported by road for four hours during the harmattan season. J. Cell. Anim. Biol., 3(2): 21-28.

30. Humes, H.D. (1984) In: Kokko, J.P. and Tannes, R.L., editors. Fluids and Electrolytes. Saunders, Philadelphia, Pennsylvania. p119-149.

31. Desroches, D. and Martin, C.R. (1986) Vitamin D, parathyroid, and thymus gland influences on seasonal variations in renal electrolyte excretion. Bone, 7(3): 223-228.

32. Dawson-Hughes, B., Harris, S.S. and Dallal, G.E. (1997) Plasma calcidol, season, and serum parathyroid hormone concentration in healthy elderly men and women. Am. J. Clin. Nutr., 65: 67-71.

33. Siddiqui, A.A. and Wilson, D.R. (1972) Primary hyperthyroidism and proximal renal tubular acidosis: Report of two cases. Can. Med. Assoc. J., 106(6): 654-659.

34. Johson, D.W. (1941) Meeting the vitamin D requirement of pigs with alfalfa hay and winter sunshine. J. Agric. Res., 63(11): 639-648.

\section{$* * * * * * * *$}

